\title{
Arkhanhelska A., Bláha O., Cholodová U. ČEŠTINA NA VOLYNI
}

Olomouc : Vydavatelství Filozofické fakulty Univerzity Palackého v Olomouci, 2020. $193 \mathrm{~s}$.

В епоху глобалізації та цифрових технологій діалектологічні студії набувають виняткового наукового значення. Як слушно й переконливо зауважив В. М. Мокієнко, «якщо ми, діалектологи, не встигнемо в останній момент зафіксувати перлини народної творчості, які ще збереглися в деяких регіонах, тоді штучний інтелект майбутнього століття (а можливо, й нинішнього) остаточно їх забуде. I невідомо, коли ще наші нащадки розкопають цей закопаний в комп'ютерні товщі природний мовний талант — талант народного мовлення» ${ }^{1}$. Ця теза $є$ особливо актуальною стосовно острівних говірок, носіями яких є нащадки переселенців, оскільки в сучасному світі побутування таких говірок з об'єктивних причин зазнає звуження й поступового занепаду. Усвідомлюючи невідкладність і безперечну актуальність, авторський колектив у складі А. Архангельської, О. Березюк, У. Холод, Р. Мерзової, К. Комарека, А. Благи підготував і видав колективну монографію «Чеська мова на Волині».

Рецензована праця має кілька особливостей. Передусім це перше в лінгвістичній славістиці дослідження мови чеського етносу крізь призму його матеріальної і духовної культури на території західних областей України - колишньої Волинської губернії царської Росії. Крім того, воно було ініційоване доцентом кафедри богемістики Філософського факультету університету імені Палацького в Оломоуці М. Вепршеком, нащадком чеських переселенців в Україну, реемігрантів до Чехії. Ця обставина зумовила інтерес до батьківщини своїх предків, їхньої мови, звичаїв і суспільного життя. У передмові М. Вепршек зазначає мету проєкту: записати спогади найстаршої генерації, прямих етнічних чехів, які народилися ще до Другої світової війни і протягом усього життя контактували 3 носіями домінантної української та російської мов колишнього СРСР. У 2018 р. усне мовлення записували на електронних носіях студенти з Чехії, Польщі та України, і це послужило корисним комунікативним засобом при опитуванні респондентів, оскільки мови саме цих трьох народів найбільшою мірою вплинули на історію міноритарних народів Волині й прилеглих областей. Коментуючи використання терміна Волинь, волинський, М. Вепршек звертає увагу на їхню традиційність стосовно спільноти чехів-емігрантів, хоча 3 погляду сучасного адміністративного поділу України місця польових досліджень розташовані в межах Житомирської і Вінницької областей та міста Луцька. Не менш важливо й те, що цей термін слугує засобом особистої ідентифікації нащадків цієї самобутньої етнічної емігрантської меншини. Як зауважує один 3 ав-

\footnotetext{
${ }^{1}$ Мокиенко В. М. Диалектная и историческая фразеология. Перспективы взаимодействия. Słowiańska frazeologia gwarowa II. / pod red. M. Raka i V. M. Mokienki. Kraków : Księgarnia Akademicka, 2020. S.84.
} 
торів, «на "старій батьківщині" уявлення про волинських чехів є набагато конкретнішим, ніж уявлення про українських чехів» (с. 96).

Монографія складається зі вступу, п'яти розділів, десяти додатків і висновків. Перший розділ, автором якого є К. Комарек, «Jazyk volyňských Čechů z hlediska nářeční stratifikace češtiny» («Мова волинських чехів 3 погляду стратифікації чеських діалектів», с. 13-45) подає опис лексики на тлі характерних ознак центральночеських, північно-східночеських і південно-західночеських наріч. Джерельною базою дослідження слугували аудіозаписи спонтанного мовлення 27 респондентів, які народилися в період 31932 по 1963 рр. в таких місцевостях: с. Комарівка Львівської області, с. Малинівка й с. Вільшанка Житомирської області, с. Миколаївка Вінницької області, міста Житомир і Луцьк. Респонденти відповідали на запитання опитувачів про сім'ю й роботу, культурні звичаї і традиції, навчання й використання чеської мови, про походження й рідний край предків. Аналіз мовленнєвого матеріалу засвідчив використання архаїчної лексики і збереження елементів діалектів, поширених на території сучасної Чеської Республіки, наприклад, funus «поховання», hledět někoho «піклуватися про когось» (можливо, під впливом укр. глядіти/ доглядати когось), vе̌dro «відро» (пор. укр. відро, poc. ведро) (с. 21), різного роду фонетичні (передусім виразна редукція довготи голосних звуків), морфологічні й синтаксичні явища: lejt, takovej lesejček, novej rok (замість літературного lit, takový lesićek, nový rok) (c. 22-23, 31), von, vořechi, vottut (замість літературного on, ořechy, odtud) (c. 23), česki učiteli (замість літературного čeští učitelé), ja tam pracoval (замість літературного já jsem tam pracoval) (c. 25) тощо. Узагальнюючи діалектні риси, наявні в мовленні волинських чехів, К. Комарек констатує практично суцільне використання нелітературних елементів, типових для всіх територіальних діалектів Чехії. Однак найцінніший висновок, що випливає з аналізованого матеріалу, сформульовано так: «Власне, йшлося про еостанній дослідницький шанс": вочевидь ми застали останню генерацію чехів на території України, які навчилися чеської мови ще в колі своєї родини» (с. 45).

Другий розділ «Zvuková stránka promluv volyňských Čechoْ» («Звукова характеристика мовлення волинських чехів», с. 47-68) написала У. Холод. Головну увагу тут зосереджено на особливостях вимови респондентів у порівнянні з нормами чеської літературної мови, а також впливові літературної української мови, з одного боку, та волинсько-подільських говірок - 3 другого, як чинників, що зумовлюють ці відхилення. Підхід до аналізу матеріалу грунтувався на кількох засадничих положеннях соціолінгвістичного плану: місце народження респондентів, місце їхнього проживання, ступінь знання чеської мови і регулярність контактів 3 нею, а також низку супровідних факторів, зокрема психоемоційний стан, що впливав на технічні показники записів.

Із залученням значного за обсягом фактичного матеріалу дослідниця визначає найтиповіші граматичні явища, опосередковані українською мовою у волинських чехів. До них зараховано вимову подвійного [1] (тобто м'якого та твердого), вимова нескладового [u], огубленого [w] замість губно-зубного $[\mathrm{v}]$, подовження або скорочення голосних звуків через рухомий динамічний наголос в українській мові, артикуляційні відмінності між твердим [у] та м'яким [i] (переважно після b, p, l, m, f), високий ступінь палаталізації d, $\mathrm{t}, \mathrm{n}, \mathrm{g}, \mathrm{k}, \mathrm{ch}$ та деяких інших приголосних після м'якого [i], тверда вимова шиплячих ž, š, č, переміщення ядра висловлювання та його інтонаційного центру (це явище часто є наслідком емфази) (с. 67).

На завершення розбору особливостей мовлення волинських чехів У. Холод робить висновок про те, що, незважаючи на панівний вплив української та російської мов, «волинська чеська мова» в основному зберегла 
ознаки, поширені на материнській території, і їі розвиток продовжується за рахунок контактів носіїв 3 живою чеською мовою (с. 68). Це засвідчують, зокрема, й типові фонетичні ознаки, спільні для мови сучасних нащадків волинських чехів і так званої загальнорозмовної чеської мови (obecná čeština), які наводить авторка: nejlepči замість nejlepši menči замість menší, štiri замість с̌tyři, dibi замість kdyby, kerej замість který, sem замість jsem тощо (c. 66).

Назва третього розділу «Lexikum, syntax a morfologie volyňské češtiny z hlediska interference s ukrajinštinou a ruštinou» («Лексика, синтаксис і морфологія волинських чехів 3 погляду інтерференції з українською та російською мовами», с. 69-98) чітко скеровує читача на коло питань, які розглядає автор А. Блага. Характерні ознаки мозаїчної мовної картини волинських чехів коментовано в контексті певних об'єктивних чинників: по-перше, майже половина респондентів походить 3 українсько-чеських родин і майже всі респонденти мають або мали одного з батьків українця без чеського предка. По-друге, лексичні і синтаксичні риси української мови проникають у мову волинських чехів у тих випадках, коли вони розказують про реалії, відмінні від чеських реалій XIX ст., наприклад, через уживання слів губернія, хутор та ін. Не можна заперечувати і значного впливу російської мови, як наприклад, uřat přiňal r'ešeňja zakryt' češskje školi «адміністрація прийняла рішення закрити чеські школи» (с. 70), а також роль суржику (хаотичного змішування елементів української та російської мовних систем), частково і субстандартних варіантів польської мови, зокрема через побутові контакти. Названі особливості утруднювали кваліфікацію мовних явищ як наслідок української, російської чи польської інтерференцій. А. Блага робить висновок про найвиразнішу рису, зафіксовану на рівні субстантивної лексики. Насамперед це прямі запозичення, напр.: Bohémija «Чехія», С̌echija «Чеська Республіка», butelka «пляшка» 3 рос. бутылка або пол. butelka, holodouka «голодівка», kladouščik з рос. кладовщик, morg «стара міра землі у XVI-XVIII ст. у Польщі, Литві та в Західній Україні (приблизно 0,56 га)» з укр. морг. Менш характерними виявилися запозичення прикметників і дієслів, пор.: nasycený «насичений», ukuš̌ějši «смачніший» від рос. вкусный, vzrosli «дорослий», pomeret «померти», nechvátit «не вистачити» 3 рос. не хватить (nechvátillo uš tech češu tag uš se museli žeňit i z ukrajincema «у ті часи їх уже не вистачало, то мусили виходити заміж за українців») (с. 73-75). Відзначено випадки розширення чи звуження семантики чеських лексем під впливом місцевих мов, напр.: čeština у значенні Чехія (чеське літературне чеська мова), d'euka 3 укр. дівка, рос. субстандартне девка, пол. diewczyna, vjek «усе життя» 3 укр. вік, рос. век, vојnа у значенні війна (чеське літературне військова служба) з укр. війна, рос. война, zет «земельна ділянка» з укр. і рос. земля (чеське літературне земля, трунт) та ін. Серед інших граматичних явищ, зумовлених інтерференційними впливами контактних мов та їхніх варіантів, автор аналізує випадки калькування на рівні словотвору, морфології і синтаксису. Ідеться про відхилення від літературних норм у парадигмі твердих і м'яких типів відмінювання, флексій числівників і займенників, реченнєвої структури тощо.

Важливим джерелом збереження етнічної належності й національної ідентичності кожного народу $є$ усна народна творчість. У цьому аспекті вельми цікавим $є$ четвертий розділ монографіï «Písňové sbírky volyňských Čechů jako prostředek zachování národní identity» («Збірки пісень волинських чехів як засіб збереження національної ідентичності», с. 99-131). Авторки А. Архангельська і Р. Мерзова подають короткий екскурс в історію еміграції чехів у Волинську губернію царської Росії (перші переселенці 1863 р.) та коментують кілька хвиль рееміграції 1947 р. і 90-х років ХХ ст. Дослідниці 
зосереджують свою увагу на характеристиці унікального видання - збірки чеських пісень з української Волині, що побачила світ 1997 р. завдяки збирацькій праці двох етнічних волинських чехів Я. Поспішила і В. Логвінової ${ }^{2}$. Відзначаючи особливість збірки, що нараховує 511 текстів, автори наголошують: «Перебування в чужому культурному та етнічному середовищі законсервувало пісні в тій формі, яку вони мали в XIX ст., і так вони передавалися від покоління до покоління протягом чотирьох генерацій. Через це науковці визнають пісенну творчість волинських чехів як документ народного фольклору всієї Чехії останньої третини XIX ст. (лише 3 мінімальними новішими вкрапленнями)» (с. 112). Тематика пісенної творчості багатогранна за змістом: вона торкається різних життєвих ситуацій, військової повинності, народних звичаїв і обрядів, урочистих сімейних подій тощо. До зображально-виражальних засобів зараховано усталені звертання (ach má drahá matičko; kamaráde můj milej; ach, bože, rozbože), численні демінутиви, типові для усної народної творчості (na nebi plály hvězdičky, když jsem ti dával hubičky; Za stodoličkou háječek; Cestička k lesíčku; Každá česká matička má na vojně synáčka), метафори (od bílého dvora po zelené louce; holka modrooká), прислів'я і приказки (Na jazyku má med, pod jazykem má led; Kdo nesázel, at' nesklizi; Láska kupovaná nikdy neni stálá; Vdávalo se motovidlo, bralo sobě dlouhé bidlo; Žena muže bit nemüže).

Аналіз збірки завершується піснею волинських авторів В. Шимека i Я. Поспішила «Pozdrav Ukrajině» («Вітання Україні»), в якій домінують українські культурні символи «соловейко» й «калина», i через слова, що пронизують душу, виражено повагу до української землі: «Let’ už, let’ už, můj slavíčku, sedni na kalině, předej pozdravủ kytičku Milé Ukrajině... A až vyjde jasný měsíc, houf děvčat se sejde, řkni jim: na Ukrajinu zapomenout nejde» (c. 130).

Головна ідея, яку обстоюють автори цього розділу, полягає в тому, що завдяки пісні чеська національна меншина Волині зберегла материнську мову, культуру і народні традиції далеко за межами «старої батьківщини». Власне, пісня для них була самим життям, як про це лаконічно сказала О. Пеца-Дмитрук із селища Петриківщина поблизу Здолбунова: «Якби я не співала, то давно б померла» (с. 111).

Останній, п’ятий розділ «Etnografický a historický výzkum volyňských Čechů» («Етнографічні й історичні дослідження волинських чехів», с. 133-156) підготувала О. Березюк. У цьому розділі подано інформацію про культурне і громадське життя на Волині до 1917 р. (діяльність пожежних осередків, спортивного об'єднання «Сокол», освітнього центру «Бесіда», організації імені Яна Амоса Коменського, часописів «Російський чех», «Чехослован», «Чехословак», чеської бібліотеки в Києві). Окремий підрозділ висвітлює культурне і громадське життя на Волині включно зі шкільництвом і видавничою діяльністю волинських чехів з 1917 р. до 1939 р.

Через опис унікальних рис кожної національної культури авторка прокладає місток до міжкультурного діалогу, що мав би забезпечити всебічний гармонійний розвиток національних меншин та етнічних груп у багатонаціональній Україні.

Ця книжка, на перший погляд суто лінгвістична, насправді змушує замислитися над багатьма філософськими питаннями життя. Одне 3 них - чи $€$ і чи взагалі можливе щастя на чужині? Ми не маємо наміру тут розвивати цю тему. Разом з тим вірогідно, що причина еміграції, рееміграції, як і сучасного українського заробітчанства, криється насамперед у суто економічній

${ }^{2}$ Pospíšil J., Lohvinová V. České písně z ukrajinské Volyně. Praha : Ústav pro etnografii a folkloristiku AV ČR, 1997. $580 \mathrm{~s}$. 
площині. У пошуках кращого життя, хай свідомо чи просто вірячи «царському слову», люди полишали свої домівки й, напевне, полишатимуть їх в усі часи.

Велику й нелегку роботу з трансформації аудіозаписів у письмову форму провів П. Поржизка, з яких найбільш репрезентативні вміщено у вигляді додатків. Цей автентичний матеріал $є$ не лише безцінним мовно-культурним спадком, але й діалектним і лінгводидактичним ресурсом. Кожен 3 текстів подає інформацію про носія аудіозапису, рік і місце народження, національність батьків, місце теперішнього проживання. Додатки розподілено за такими темами: «Festival sovětské a československé mládeže» («Фecтиваль радянської та чехословацької молоді»), «Jak jsme chránili češtinu» ( «Як ми зберігали чеську мову»), «Kolektivizace na Ukrajině» («Колективізація в Україні»), «Hladomor a dušičky» («Голодомор і поминання померлих»), «Velká rodina a česká svatba» («Велика сім'я і чеське весілля»), «Rodinný život v Nikolajevce» («Сімейне життя в Ніколаєвці»), «Dětská školka» («Дитячий садок»), «Sňatková politika Čechů» («Шлюбна політика чехів»), «Slavení Vánoc» («Святкування Різдва»), «Putování češtiny přes generace» («Мандри чеської мови через покоління»).

Рецензована монографія доповнює попередні дослідження, присвячені мові чехів-переселенців у різних регіонах України (див. праці 3. І. Мячинової, Й. Андерша, Я. Янчакової і П. Янчака). Уміщений у ній матеріал може слугувати підгрунтям для контрастивних студій у плані динаміки мовних змін на тлі соціальних обставин.

Книжка завершується символічними словами: «Ми віримо, що цією працею ми принаймні зробимо внесок у поширення інформації про наших співвітчизників в Україні, а також в історію міжслов'янських культурних взаємин» (с. 178). У контексті сказаного можна лише підтвердити, що вона відповідає найважливішим запитам сучасності. Доля волинських чехів не перестає цікавити науковців. У цьому переконує видана цьогоріч праця чеської авторки Д. Мартінкової ${ }^{3}$.

Якщо говорити про загальне враження від монографії «Чеська мова на Волині», необхідно відзначити об'єднувальне шанобливе ставлення авторського колективу до мови краян (starousedlíků), які по волі чи по неволі опинилися колись далеко за межами рідної землі. Враження читача підсилюють фотодокументи, які органічно доповнюють текстовий матеріал.

Отже, можемо констатувати, що з'явилося оригінальне, актуальне й корисне видання, яке дає уявлення про результати мовно-культурної взаємодії двох слов'янських народів - українського й чеського - протягом XIX - початку XXI ст. Праця оломоуцьких лінгвістів продовжує найкращі традиції західноєвропейської діалектології. Водночас дослідження самобутньої культурної спадщини чеських емігрантів Волині ще не можна вважати завершеним. Зібраний мовний матеріал дає імпульс для подальших розвідок, зокрема й за участі українських богемістів.

\section{Л. Даниленко}

Київський національний університет імені Тараса Шевченка

м. Київ, Україна

Електронна пошта: dankoua@ukr.net https://orcid.org/0000-0002-1812-973X

${ }^{3}$ Martinková D. Na pozvání cara: př́iběh Čechů na ruské, polské, sovětské a ukrajinské Volyni. Praha : Sdružení Čechů z Volyně a jejich přátel, z.s., 2021. 334 s. 


\section{Danylenko}

Taras Shevchenko National University of Kyiv

Kyiv, Ukraine

E-mail:dankoua@ukr.net

https://orcid.org/0000-0002-1812-973X

\section{Arkhanhelska A., Bláha O., Cholodová U. \\ ČEŠTINA NA VOLYNI}

Olomouc : Vydavatelství Filozofické fakulty Univerzity Palackého v Olomouci, 2020. $193 \mathrm{~s}$.

Дата надходження до редакції - 29.09.2021

Дата затвердження редакцією - 30.09.2021

DOI 10.33190/0027-2833-321-2021-6-006

\section{Grzegorczykowa R.}

\section{JEZYK W SŁUŻBIE MYŚLI: SZKICE Z DZIEJÓW POLSKIEGO SŁOWNICTWA / red. nauk. M. Laziński, M. Chojnacka-Kuraś.}

Warszawa : Wyd-wo Uniw-tu Warszawskiego, 2021. 288 s.

Професор Рената Гжегорчикова є легендарною постаттю в сучасній польській лінгвістиці й лінгводидактиці. Її довголітня професійна діяльність нерозривно пов'язана з Інститутом польської мови Варшавського університету, де її вчителем був видатний мовознавець В.Дорошевський. Бібліографія iii праць налічує понад 200 позицій і обіймає проблематику таких напрямів і галузей, як загальне і зіставне мовознавство, когнітивна лінгвістика й лінгвопрагматика, теолінгвістика, граматика, особливо словотвір і синтаксис, лексикологія польської мови тощо, і містить як власне наукові монографії і статті, так і підручники й посібники, відомі багатьом поколінням полоністів у Польщі і далеко за іï межами ${ }^{1}$. Серед наукових і науково-дидактичних заходів, ініціаторкою яких була Р.Гжегорчикова, можна згадати традиційні «Семантичні середи» в Інституті польської мови (співорганізатором яких була проф. Ядвіга Самбор) і міжнародну програму «Зіставна лексична семантика», що в них брали участь і українські мовознавці, у тому числі й співавторка цієї рецензії.

19 червня пані Гжегорчикова відзначила своє 90-ліття. До цієї дати у видавництві Варшавського університету вийшла монографія ювілярки «Мова на службі думки: нариси $з$ історії польської лексики». Ми окреслюємо цю книжку саме як монографію, хоча вона об'єднує в собі й розвідки, що були опубліковані раніше (деякі 3 них переглянуті й доповнені), і результати нових досліджень авторки. Але водночас ці складники структури книжки утворюють єдине ціле зі своєю наскрізною темою і підпорядкованими їй конкретнішими підтемами й сюжетами — як загальнотеоретичними, так і належними до галузі лінгвополоністики, що віддавна цікавили Р. Гжегорчи-

1 Див.: Mikołajczuk A. O życiu zawodowym i dokonaniach naukowych Profesor Renaty Grzegorczykowej. Etnolingwistyka. 2012. T. 24. S. 7-10.

(C) Т. ЧЕРНИШ, С. С. ЄРМОЛЕНКО, 2021 